\title{
Identification and Assesment of the Specific Absorption Rate (SAR) Generated by the most used Telephone in Peru in 2017
}

\author{
Natalia Indira Vargas-Cuentas ${ }^{1}$ \\ Image Processing Research Laboratory (INTI-Lab) \\ Universidad de Ciencias y Humanidades (UCH) \\ Lima, Peru
}

\author{
Mark Clemente-Arenas ${ }^{2}$ \\ CSE-HF \\ Universidad Nacional Tecnológica de Lima Sur(UNTELS) \\ Lima, Peru
}

\author{
Avid Roman-Gonzalez ${ }^{3}$ \\ Image Processing Research Laboratory (INTI-Lab) \\ Universidad de Ciencias y Humanidades (UCH) \\ Lima, Peru
}

\author{
Roxana Moran-Morales ${ }^{4}$ \\ Instituto Nacional de Investigación y Capacitación de \\ Telecomunicaciones INICTEL-UNI \\ Universidad Nacional de Ingeniería (UNI), Lima, Peru
}

\begin{abstract}
According to the World Health Organization (WHO) it is estimated that between 5 and $10 \%$ of the population is electro sensitive, the excessive or prolonged exposure to electromagnetic waves can damage health. Currently the electromagnetic radiation generated by wireless mobile telephony involves our daily lives, since it is reported that there are more than 5 billion cell phone users. Each country establishes its own relative national standards on exposure to electromagnetic fields, which Peru lacks. Nevertheless, they are based in standards that has not been revised since 1996. This contribution seeks to identify the Specific Absorption Rate (SAR) generated by the most used mobile phone in Peru in 2017 using the ComoSAR measuring system in the GSM (Global System for Mobile communications) band at a frequency of $900 \mathrm{MHz}$. The results obtained will evaluate the behavior of electromagnetic waves by affecting the emulated tissues of body density and dielectric constant. The maximum SAR values recorded in the measurement were $0.05 \mathrm{~W} / \mathrm{Kg}$ for a $1 \mathrm{~g}$ cube and $0.02 \mathrm{~W} / \mathrm{Kg}$ for a $10 \mathrm{~g}$ cube. On the other hand, the average values obtained were $0.046 \mathrm{~W} / \mathrm{Kg}$ for a $1 \mathrm{~g}$ cube and $0.019 \mathrm{~W} / \mathrm{Kg}$ for a $10 \mathrm{~g}$ cube. The SAR values measured in the conditions of the experiment are below that what is indicated by the US standard and the European standard of SAR values.
\end{abstract}

Keywords—Electromagnetic radiation; SAR; ComoSAR; GSM

\section{INTRODUCTION}

Excessive or prolonged exposure to electromagnetic waves generated by radio frequency (RF) can damage human health [1], currently globally according to the Association of Internet and Cellular Telecommunications there were more than 400 million cell phone subscribers in the United States in 2017. Globally, there are more than 5 billion cell phone users.

Although it is not appreciated, excessive or prolonged exposure to electromagnetic waves generated by radio frequency (RF) can damage health and its effects are cumulative [2].
The effects induced by electromagnetic radiation can be thermal and non-thermal, which are the ones that generate the greatest risk when producing biological changes [3]. According to the World Health Organization (WHO) [4] it is estimated that between 5 and $10 \%$ of the population is electro sensitive and among the most frequent symptoms appear headaches, insomnia, irritability, depression or increased risk of cancer, among others.

In order to set the exposure limits, scientific research must identify the threshold at which the first effects on health are manifested, but no tests can be performed on humans, therefore other alternatives for experimentation were found by the Institute of Electrical and Electronics Engineers (IEEE) [5] and the International Electrotechnical Commission (IEC) [6, 7]. It is important to mention that there is no single level above which exposure becomes dangerous to health; on the contrary, the potential risk to health increases gradually as the level of exposure of people increases [8].

The electromagnetic radiation generated by wireless mobile telephony involves our daily lives, much more today, because in the last decade it has increased exponentially in urban centers and in each of the homes.

Each country establishes its own relative national standards on exposure to electromagnetic fields. However, most of these national standards are based on the recommendations of the International Commission for Non-Ionizing Radiation Protection (ICNIRP). This non-governmental organization, formally recognized by WHO, evaluates the results of scientific studies conducted worldwide.

Table I summarizes the recommended exposure limits corresponding to the types of technologies that have caused concern in society. The last update of these guidelines was made in April 1998. 
TABLE I. RECOMMENDED EXPOSURE LIMITS

\begin{tabular}{|l|l|l|l|l|l|}
\hline \multirow{2}{*}{ Frequency } & \multicolumn{2}{l|}{$\begin{array}{l}\text { Frequency of the European } \\
\text { electricity grid }\end{array}$} & \multicolumn{2}{l|}{ Frequency of mobile phone base stations } & \multicolumn{2}{l|}{ Frequency of microwave ovens } \\
\cline { 2 - 6 } & $50 \mathrm{~Hz}$ & $50 \mathrm{~Hz}$ & $900 \mathrm{MHz}$ & $1,8 \mathrm{GHz}$ & $2,45 \mathrm{GHz}$ \\
\cline { 2 - 6 } & Electric field $(\mathrm{V} / \mathrm{m})$ & Magnetic field $(\mu \mathrm{T})$ & $\begin{array}{l}\text { Power density } \\
(\mathrm{W} / \mathrm{m} 2)\end{array}$ & $\begin{array}{l}\text { Power density } \\
(\mathrm{W} / \mathrm{m} 2)\end{array}$ & $\begin{array}{l}\text { Power density } \\
(\mathrm{W} / \mathrm{m} 2)\end{array}$ \\
\hline $\begin{array}{l}\text { Exposure limits for the } \\
\text { population }\end{array}$ & 5000 & 100 & 4.5 & 9 & 10 \\
\hline Occupational Exposure Limits & 10000 & 500 & 22.5 & 45 &. \\
\hline
\end{tabular}

Given this, the Council of Europe establishes maximum exposure levels for wireless telephony in indoor areas of 0.6 volts per meter $(0.1$ microwatts per square centimeter or $\mu \mathrm{W} /$ $\mathrm{cm}^{2}$ ).

The Federal Communications Commission (FCC) is the entity that decides how much radiation it is allowed to emit to cell phones in the United States. Currently, the limit defined by the FCC is $1.6 \mathrm{~W} / \mathrm{Kg}$ per $1 \mathrm{~g}$ of tissue. However, this standard has not been revised since 1996 [9].

Specific Absorption Rate (SAR) values indicate the highest level of exposure to electromagnetic radiation measured. In Europe, the SAR limit for mobile devices is set at $2 \mathrm{~W} / \mathrm{Kg}$ per $10 \mathrm{~g}$ of tissue. This standard conforms to the ICNIRP 1998 guidelines, as well as the IEC standards and is determined by CENELEC [10].

In Peru, the established SAR value is the recommended by ICNIRP of $2 \mathrm{~W} / \mathrm{Kg}$ averaged over a tissue mass of $10 \mathrm{~g}(0.02$ $\mathrm{W}$ absorbed in any mass of $10 \mathrm{~g}$ of tissue in the head) [11].

This project seeks to identify the Specific Absorption Rate generated by the most used mobile phone in Peru using SAR measuring equipment, for the study of the distribution and levels of the electromagnetic field perceived by the human body when exposed to the electromagnetic waves generated by radio frequency.

The main importance of this research is that the results obtained will evaluate the behavior of electromagnetic waves by affecting the emulated tissues of body density and determine the impact that these mobile devices have on humans.

Based on the results obtained, consumers can be provided with information on the possible risks of prolonged use of mobile equipment and formulate safety advice to protect sensitive subjects such as children and the elderly.
Finally, the current radiation standards for cell phones can be reviewed and it will be important to try to propose and set standards to limit cell phone radiation in Peru.

\section{IDENTIFICATION OF THE MOST USED PHONE IN PERU IN 2017}

According to the Lima Chamber of Commerce (CCL) in 2016 and 2017, the third most imported product to the country was mobile phones [12], as can be seen in Table II.

It can be seen the total imports by companies in Table III, we can see in the top positions companies such as Samsung, LG, Huawei, among others [13].

In 2016, for example, 12.3 million smartphones were imported, of which five telephone brands were the most consumed in the Peruvian market [14].

According to the CCL, there is leadership in total imports of the following brands: Samsung (22.2\%), Huawei $(21.3 \%)$, Apple (13.6\%), LG (10.6\%) and Morotola (7.8\%) [15].

According to Device Atlas in 2017, the three most used phones were Samsung and Motorola [9]. In the first place is the Samsung Galaxy J7, second to the Samsung Galaxy J5 and third is the Motorola Moto G [16].

As can be seen in Table IV, in five South American countries, the most used devices are Samsung and Motorola, among which the most preferred models are the Samsung Galaxy J5, Galaxy J7, Galaxy J1 Ace and the Motorola Moto $\mathrm{G}$.

According to Table III, the most used cell phone in Peru in 2017 was the Samsung Galaxy J7, in this sense in this study that equipment will be used to be able to measure and identify the specific percentage of absorption generated by this mobile device.

TABLE II. MAIN IMPORTED PRoducts IN PERU - JANUARY To DeCEMBER 2016 / 2017

\begin{tabular}{|l|l|l|l|l|l|}
\hline RK 17 & RK 16 & Item & Main Imported Products & $\mathbf{2 0 1 6}$ & $\mathbf{2 0 1 7}$ \\
\hline 1 & 1 & 2709000000 & Crude of oil or bituminous ore & 2,471 \\
\hline 2 & 2 & 2710192111 & Diesel 2, with a sulfur content less than or equal to 50 ppm & 1,633 & 1,293 \\
\hline 3 & 3 & 8517120000 & Mobile phones (cell phones) and other wireless networks & 1,540 & 1,127 \\
\hline 4 & 4 & 8703239020 & $\begin{array}{l}\text { Other vehicles assembled with a spark ignition reciprocating piston or } \\
\text { reciprocating piston engine, for the carriage of persons, with a cylinder capacity } \\
\text { greater than 1,500 cc but less than or equal to 3,000 cc. }\end{array}$ & 793 \\
\hline 5 & 7 & 1005901100 & Yellow hard corn, except for sowing & 743 \\
\hline
\end{tabular}


TABLE III. TOTAL IMPORTS BY COMPANIES - JANUARY TO DECEMBER 2016 / 2017

\begin{tabular}{|c|c|c|c|c|c|c|}
\hline RK 17 & RK 16 & Importing companies & 2016 & 2017 & VAR.\% 17/16 & Part.\% 2017 \\
\hline 1 & 2 & Refinería La Pampilla S.A.A. & 1,860 & 2,705 & $45.4 \%$ & $6.8 \%$ \\
\hline 2 & 1 & Petróleos Del Peru Petroperu S.A. & 2,305 & 2,607 & $13.1 \%$ & $6.5 \%$ \\
\hline 3 & 4 & Toyota Del Peru S.A. & 608 & 592 & $-2.7 \%$ & $1.5 \%$ \\
\hline 4 & 7 & Motorindustria S.A. & 469 & 527 & $12.2 \%$ & $1.3 \%$ \\
\hline 5 & 6 & Samsung Electronics Peru S.A.C. & 474 & 468 & $-1.3 \%$ & $1.2 \%$ \\
\hline 6 & 8 & Alicorp S.A.A. & 371 & 454 & $22.5 \%$ & $1.1 \%$ \\
\hline 7 & 12 & Pure Biofuels Del Peru S.A.C. & 305 & 434 & $42.1 \%$ & $1.1 \%$ \\
\hline 8 & 10 & Lg Electronics Peru S.A. & 356 & 377 & $5.7 \%$ & $0.9 \%$ \\
\hline 9 & 17 & Corporación Aceros Arequipa S.A. & 272 & 333 & $22.8 \%$ & $0.8 \%$ \\
\hline 10 & 19 & Huawei Del Peru Sac & 238 & 321 & $35.1 \%$ & $0.8 \%$ \\
\hline 11 & 15 & Diveimport S.A. & 284 & 320 & $12.8 \%$ & $0.8 \%$ \\
\hline 12 & 9 & America Movil Peru S.A.C & 362 & 319 & $-11.7 \%$ & $0.8 \%$ \\
\hline 13 & 14 & Automotores Gildemeister-Peru S.A. & 299 & 311 & $4.1 \%$ & $0.8 \%$ \\
\hline 14 & 13 & Southern Peru Copper & 299 & 279 & $-6.7 \%$ & $0.7 \%$ \\
\hline 15 & 16 & Adm Andina Peru S.R.L. & 283 & 269 & $-4.9 \%$ & $0.7 \%$ \\
\hline 16 & 38 & Molinos \& Cia S.A. & 121 & 260 & $115.9 \%$ & $0.7 \%$ \\
\hline 17 & 21 & Contilatin Del Peru S.A. & 232 & 256 & $10.1 \%$ & $0.6 \%$ \\
\hline 18 & 18 & Gloria S.A. & 271 & 232 & $-14.3 \%$ & $0.6 \%$ \\
\hline 19 & 30 & Cargill Americas Peru S.R.L. & 184 & 232 & $25.7 \%$ & $0.6 \%$ \\
\hline 20 & 27 & Volvo Peru S.A. & 198 & 229 & $16.0 \%$ & $0.6 \%$ \\
\hline \multicolumn{3}{|c|}{ Other importing companies } & 27,658 & 28,384 & $2.6 \%$ & $71.1 \%$ \\
\hline \multicolumn{3}{|l|}{ TOTAL } & 37,449 & 39,909 & $6.6 \%$ & $100.0 \%$ \\
\hline
\end{tabular}

TABLE IV. MOST USED CELL PHONES IN SOUTH AMERICA 2017

\begin{tabular}{|l|l|l|l|}
\hline Country & $\mathbf{\# 1}$ & $\mathbf{\# 2}$ & $\mathbf{\# 3}$ \\
\hline Argentina & Motorola Moto G & Samsung Galaxy J7 & Samsung Galaxy J1 Ace \\
\hline Brazil & Motorola Moto G & Samsung Galaxy J5 & Motorola Moto G 2nd Gen \\
\hline Chile & Samsung Galaxy J5 & Motorola Moto G & Samsung Galaxy J7 \\
\hline Ecuador & Samsung Galaxy J5 & Samsung Galaxy J7 & Samsung Galaxy J1 Ace \\
\hline Peru & Samsung Galaxy J7 & Samsung Galaxy J5 & Motorola Moto G \\
\hline
\end{tabular}

\section{SPECIFIC AbSORPtion RATE (SAR) MEASUREMENT}

The specifications of the mobile equipment to be measured must be found. Perform 3D scanning of the distribution of electromagnetic fields in the human body in the $900 \mathrm{MHz}$ frequency band using the ComoSAR Specific Absorption Rate measuring equipment. Use the $900 \mathrm{MHz} \mathrm{Head}$ liquid in the device phantom, perform the measurement with the mobile phone connected to a call, position the phone on the right side and on the left side of the phantom in the cheek and tilt positions.

Obtain the results of the 2D scan area by finding the position of the hot spots and find the results of the $3 \mathrm{D}$ zoom scan by finding the results of the $10 \mathrm{~g}$ cube and the $1 \mathrm{~g}$ cube.

\section{A. Characteristics of the Mobile Device}

The Samsung Galaxy $\mathbf{J} 7$ in Fig. 1, is a mid-range Smartphone of the Galaxy J line, among its many features [17] we highlight an eight-core $1.5 \mathrm{GHz}$ processor, Android 6.0 operating system, the battery capacity is $3000 \mathrm{mAh}$ and it is of the Li-ion type (lithium ions).

According to the technical data sheet, the Samsung Galaxy J7 has a Qualcomm Snapdragon 615 SoC (System on a Chip). This SoC has an RF system of 3rd generation power-efficient LTE, with 7-mode bands, and lower power and PCB reduction. [18].

The operating system of the Samsung Galaxy J7 is the Android 6.0.1 Marshmallow, the device has proximity, light and accelerometer sensors.

It also has an internal storage of $16 \mathrm{~GB}$, external microSD storage of up to $128 \mathrm{~GB}$ and $2 \mathrm{~GB}$ of RAM [17].

As can be seen in Fig. 2, the dimensions of this mobile device are $152.2 \times 79.1 \times 7.9 \mathrm{~mm}$, its weight is $168 \mathrm{~g}$ and its volume is $95.11 \mathrm{~cm}^{3}$. On the other hand it has a resolution of 1920 x 1080 and a density of 401 ppi [18]. 


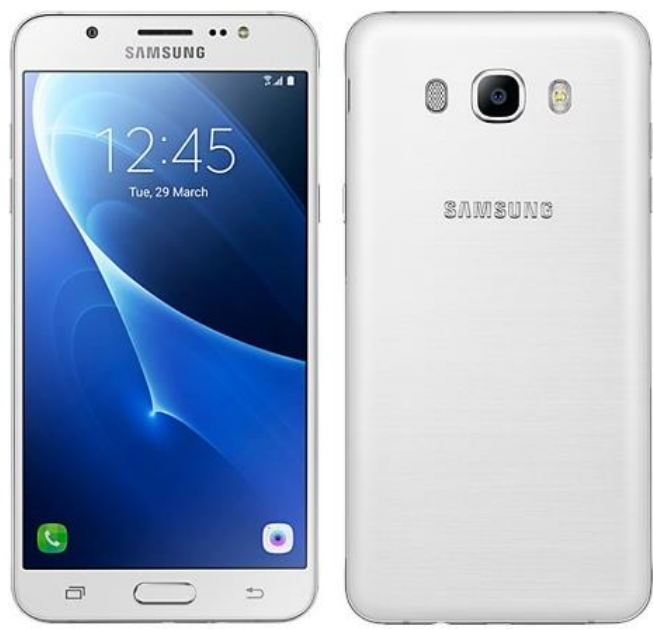

Fig. 1. Samsung Galaxy J7.

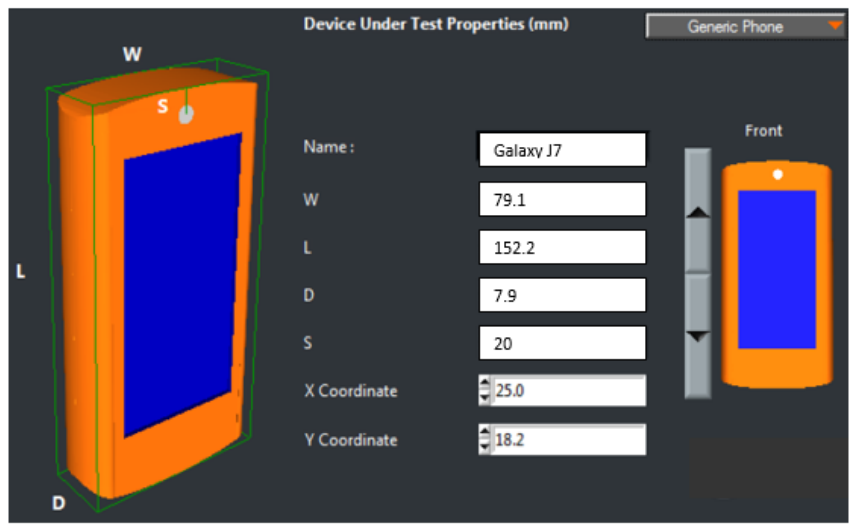

Fig. 2. Samsung Galaxy J7 Dimensions.

The mobile network technologies that the phone supports are the following: GSM (Global System for Mobile communications), TD-SCDMA (Time Division Synchronous Code Division Multiple Access), UMTS (Universal Mobile Telecommunications System) y LTE (Long Term Evolution).

According to [17] the Specific Absorption Rate (SAR) of this mobile device when the device is held in the head next to the ear in conversation position is $0.18 \mathrm{~W} / \mathrm{Kg}$ per $10 \mathrm{~g}$ of tissue, on the other hand the SAR value of this mobile equipment when the device is kept close to the body at the level of the hip is $0.265 \mathrm{~W} / \mathrm{Kg}$ per $10 \mathrm{~g}$ of tissue. On the other hand, as specified by [18] the SAR values for every $10 \mathrm{~g}$ of tissue is $0.503 \mathrm{~W} / \mathrm{Kg}$ for the head and $0.373 \mathrm{~W} / \mathrm{Kg}$ for the body, in addition the SAR values for every $1 \mathrm{~g}$ of tissue is 1.14 $\mathrm{W} / \mathrm{Kg}$ for the head and $1.32 \mathrm{~W} / \mathrm{Kg}$ for the body.

The Federal Office for Radiation Protection (BfS) that is a German entity that has conducted measurements of the radiation values of the mobile phones following standardized procedures and has published the information.

Measurements made by BfS [19] of the Galaxy J7 mobile phone, indicate that the SAR values per $10 \mathrm{~g}$ of tissue is 0.57 $\mathrm{W} / \mathrm{Kg}$ for the head and $1.33 \mathrm{~W} / \mathrm{Kg}$ for the body at a measuring distance of $0.5 \mathrm{~cm}$.
It is important to mention that devices not exceeding 0.6 W/Kg during operation fulfil an important criterion for obtain the "Blue Angel" eco label. As can be observed the Samsung Galaxy J7 only complies with one part of the requirement, since the SAR value in the body is very high.

\section{B. ComoSAR Equipment Description}

To measure SAR from the Samsung Galaxy J7, the ComoSAR 30-6000 MHz system with double phantom inside of anechoic chamber is used. The equipment was obtained through the scientific equipment grant with code RNR N ${ }^{\circ} 285$ INNOVATEPERU-EC-2017' of INICTEL-UNI and UCH, funded by Ministry of Production, through the Innóvate-Perú Program.

Mainly the Microwave Vision Group (MVG) ComoSAR measurement system and certification system has three main components: The SAR bench, the instrumentation and the remote computer, as can be seen in the following block diagram in Fig. 3.

The instrumentation component has the necessary equipment to perform system calibration tests, noise evaluation, liquid properties measurement and finally the realization of SAR measurements of some device.

On the other hand, the remote computer component mainly has a computer that will have the OpenSAR software, which is the element that allows interaction between the Bench SAR, devices such as the probe, the multimeter, the communication tester and the end user.

The ComoSAR system has a semi anechoic chamber, which is a shielded room that provides an isolation above $100 \mathrm{~dB}$. In other words, it reduces and blocks any external electromagnetic field. This is necessary to perform standardized SAR measurements.

The SAR bench is located inside the semi anechoic chamber. It is composed of different subsystems, such as the KUKA arm robot, the E-field probe, two SAM (Specific Anthropomorphic Mannequin) phantom tables, liquids with human like dielectric properties, a video positioning system in order to guide the probe and DUT (Device Under Test) holders for positioning the mobile phone.

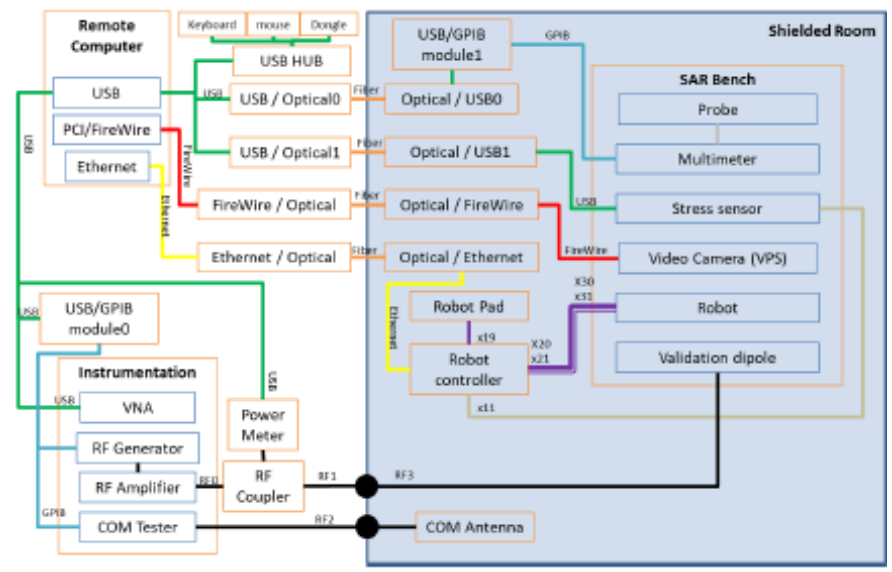

Fig. 3. Block Diagram of the ComoSAR Measurement System. 


\section{Mobile Device Measurement with the ComoSAR}

For measurement purposes, the first step is to select and to place the handset in a correct position. The positions displayed in Fig. 4, must be taken into account.

The first position is the called cheek position in which the headset is in contact with the ear and the front of the phone is fully in contact with the cheek of the phantom. On the other hand the second position is called tilt position, where the mobile device moves away from the mouth and forms an angle of $15^{\circ}$ with the head of the phantom.

As can be seen in Fig. 5, it is necessary to use the DUT holder and match it with the vertical marks that the phantom has to make sure that the mobile device is in the correct position to perform the corresponding measurements.

Once we have the mobile device well located, we can proceed to perform SAR measurements, for which we will have the configuration observed in Fig. 6.

The ComoSAR system will allow to determine the distribution of SAR within the phantom that represents the human body, as can be seen in the figure to make the corresponding measurements it will be necessary to use the main computer of the system, the OpenSAR software, the sixaxis robot, the data acquisition system, the E-field probe, the tissue simulator liquid, the mobile device (DUT) and the DUT holder.
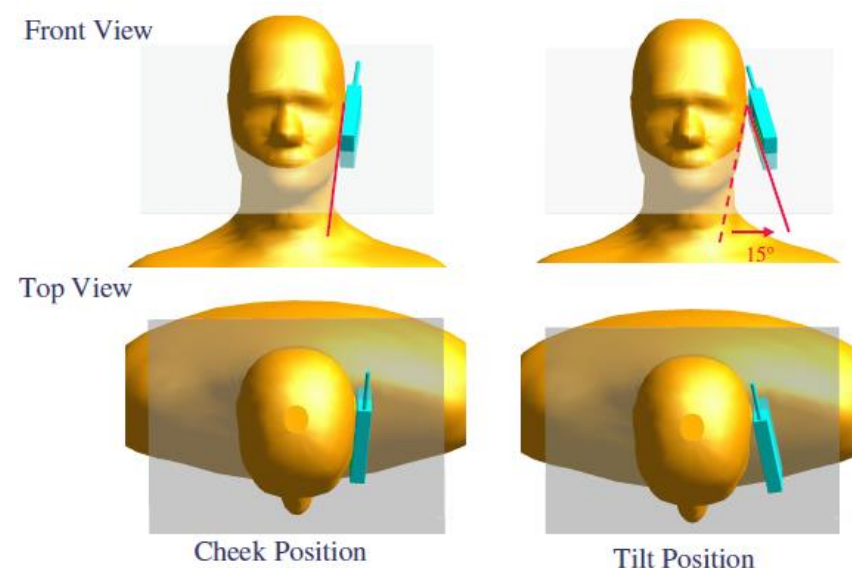

Fig. 4. Cheek and Tilt Positions [20]

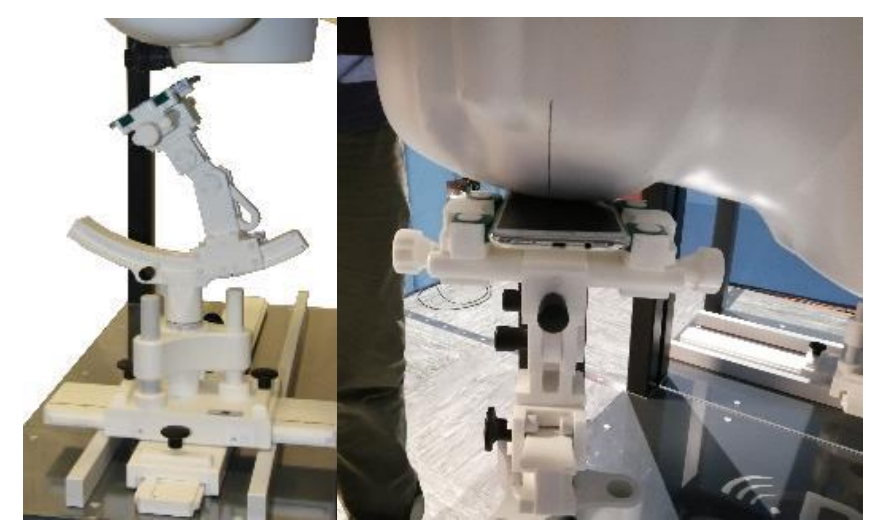

Fig. 5. Correct Position of the Device under Test (DUT) Holders.

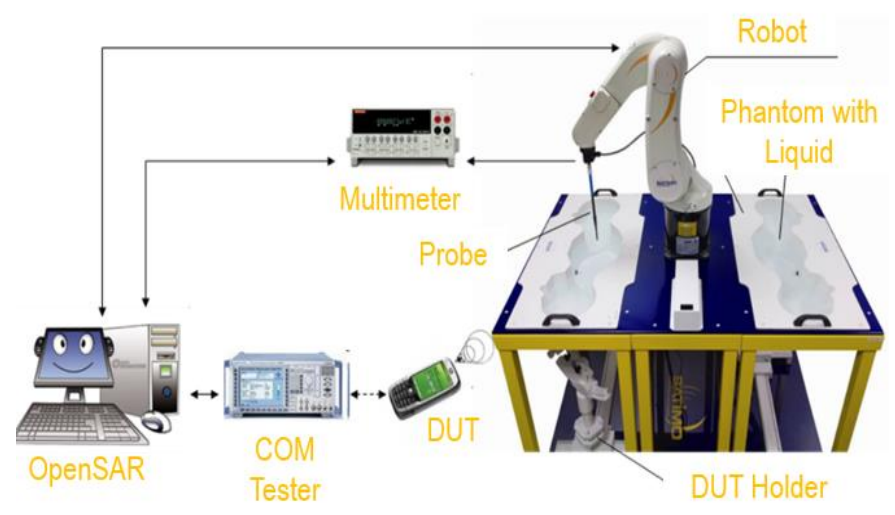

Fig. 6. DUT SAR Evaluation [21].

Specific Absorption Rate (SAR) measurements will be made on the Samsung Galaxy J7 device, in a $900 \mathrm{MHz}$ GSM network, with a head simulating liquid that has a relative permittivity of 41.5 in addition to a conductivity of 0.97 (S / $\mathrm{m})$. It is important that the phone battery is well charged during each measurement.

For the measurement procedure a call is established with the mobile device, then the desired measurement must be configured in the OpenSAR software, as can be seen in Fig. 7.

In the OpenSAR software, a connection with the robot, the multimeter and the communication tester must be established. The type of probe and phantom to be used must be selected, on the other hand the measurement parameters must be indicated, such as the type of device and its dimensions, the position of the device, the section of the phantom to be evaluated, the type of liquid, the frequency band of study, the standard and the channel.

The OpenSAR software computes the results to give a SAR value in a $1 \mathrm{~g}$ or $10 \mathrm{~g}$ mass, these results will be observed in the next section.

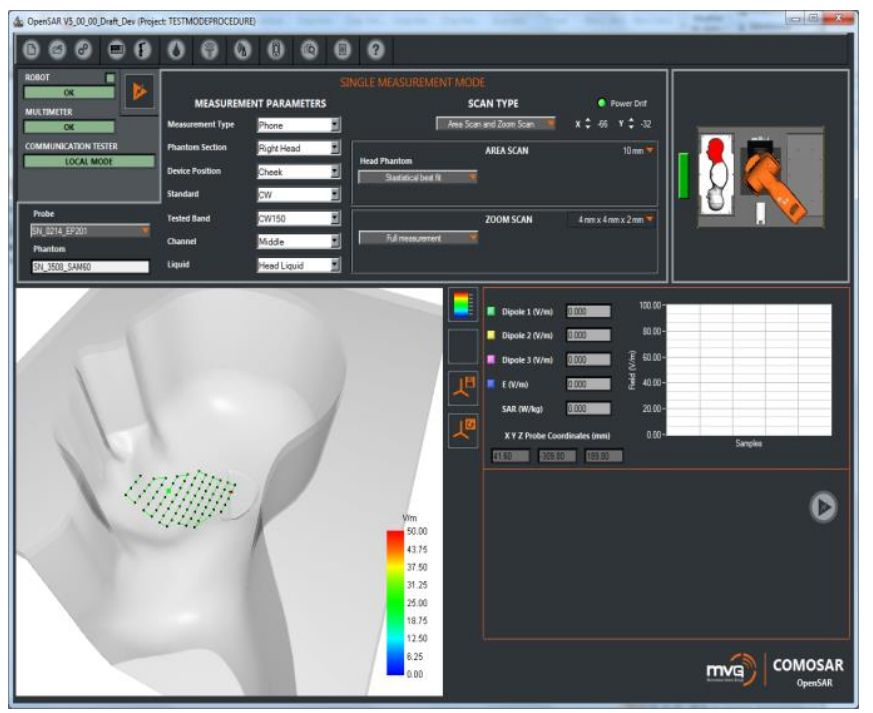

Fig. 7. Software OpenSAR Configuration. 


\section{RESUltS}

To obtain the SAR measurements, a scan area was first performed on the projection given by the dimensions of the mobile device. From this first scan the maximum points or hot spots were identified, then the SAR is evaluated in a cube above these maximum local, as can be observed in Fig. 8.

Table $\mathrm{V}$ shows the experimental conditions configured to perform the corresponding SAR measurements on the selected device.

For a GSM band at a frequency of $900 \mathrm{MHz}$, for a medium channel, in a section of the phantom that represented the right profile of the head, with a cheek type position the following SAR values have been obtained for the Samsung mobile device Galaxy J7, as can be observed in Table VI.

The maximum SAR values recorded in the measurement were $0.05 \mathrm{~W} / \mathrm{Kg}$ for a $1 \mathrm{~g}$ cube and $0.02 \mathrm{~W} / \mathrm{Kg}$ for a $10 \mathrm{~g}$ cube. On the other hand, the average values obtained were $0.046 \mathrm{~W} / \mathrm{Kg}$ for a $1 \mathrm{~g}$ cube and $0.019 \mathrm{~W} / \mathrm{Kg}$ for a $10 \mathrm{~g}$ cube.

Table VII shows the comparison of the results obtained from SAR with the values allowed by the European and American standards.

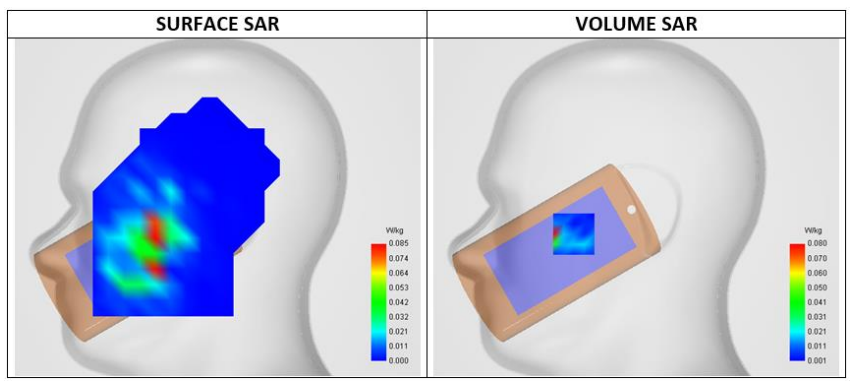

Fig. 8. Surface Scan and Volume Scan Results.

TABLE V. EXPERIMENTAL CONDITIONS

\begin{tabular}{|l|l|}
\hline Phantom & Right head \\
\hline Device position & Cheek \\
\hline Band & GSM900 \\
\hline Channels & Middle \\
\hline Signal & TDMA (Crest factor: 8.0$)$ \\
\hline
\end{tabular}

TABLE VI. MEASURED SPECIFIC ABSORPTION RATE (SAR)

\begin{tabular}{|l|l|}
\hline Specific Absorption Rate (SAR) & Measured value (W/Kg)) \\
\hline SAR $10 \mathrm{~g}$ & 0.019266 \\
\hline SAR 1 g & 0.046403 \\
\hline
\end{tabular}

TABLE VII. COMPARISON OF THE MEASURED SAR VALUES WITH THE STANDARDS

\begin{tabular}{|l|l|l|l|l|}
\hline & USA & Europe/Asia & Peru & $\begin{array}{l}\text { Measured } \\
\text { values } \\
\text { (Galaxy J7) }\end{array}$ \\
\hline SAR 10 g (W/Kg) & - & 2 & 2 & 0.019266 \\
\hline SAR 1 g (W/Kg) & 1.6 & - & - & 0.046403 \\
\hline
\end{tabular}

As can be seen in the previous table, the SAR values measured in the conditions of the experiment are well below what is indicated by both the US standard and the European standard of SAR values for $10 \mathrm{~g}$ and $1 \mathrm{~g}$ of tissue, respectively.

\section{CONCLUSIONS}

Based on the results obtained, safety advice can be formulated for the use of cell phones, especially to protect sensitive subjects such as children and the elderly. On the other hand, consumers can be provided with information on the possible risks of prolonged use of mobile equipment.

Radiation standards for cell phones can also be examined in order to protect the health of consumers and to provide useful information to the consumer.

Finally, it will be important to try to propose and establish technical standards to cell phone importation in order to verify if wireless handsets are working below the limits on exposure to non-ionizing radiation in Peru.

It is important to continue with this type of research because as mobile communications are evolving really fast, and new frequency spectrum is being used, standardized testing needs to be updated accordingly. The future work of this research will aim to establish the experiment with a base station simulator, in order to establish a call with the maximum output power for several of the new frequency bands that are being used for emerging technologies. In addition to performing SAR measurements on other new mobile devices of interest. On the other hand, in order to be able to continue with future work in the same research track and to acquire complementary equipment and carry out additional studies, it is possible to apply for different research funds.

\section{ACKNOWLEDGMENT}

This research work was supported by INNOVATE Perú, 'Contrato RNR Nº 285-INNOVATEPERU-EC-2017'.

\section{REFERENCES}

[1] Takei, R., Nagaoka, T., Saito, K., Watanabe, S., \& Takahashi, M. (2017). SAR variation due to exposure from a smartphone held at various positions near the torso. IEEE Transactions on Electromagnetic Compatibility, 59(2), 747-753.

[2] Guideline, ICNIRP. (1998). Guidelines for limiting exposure to timevarying electric, magnetic, and electromagnetic fields (up to $300 \mathrm{GHz}$ ). Health phys, 74(4), 494-522.

[3] Hardell, L. (2017). World Health Organization, radiofrequency radiation and health-a hard nut to crack. International journal of oncology, 51(2), 405-413.

[4] World Health Organization (WHO), Electromagnetic fields (EMF), December 2017.

[5] IEEE Standard 1528-2013 IEEE Recommended Practice for Determining the Peak Spatial-Average Specific Absorption Rate (SAR) in the Human Head from Wireless Communications Devices: Measurement Techniques.

[6] IEC 62209-1 Human exposure to radio frequency fields from hand-held and body-mounted wireless communication devices-Human models, instrumentation, and procedures-Part 1: Procedure to determine the specific absorption rate (SAR) for hand-held devices used in close proximity to the ear (frequency range of $300 \mathrm{MHz}$ to $3 \mathrm{GHz}$ ).

[7] IEC 62209-2 Human exposure to radio frequency fields from hand-held and body-mounted wireless communication devices-Human models, instrumentation, and procedures - Part 2: Procedure to determine the specific absorption rate (SAR) in the head and body for $30 \mathrm{MHz}$ to 6 
GHz handheld and body-mounted devices used in close proximity to the body.

[8] Parthasarathy, S. R., \& Tukimin, R. (2018, January). Residential exposure from extremely low frequency electromagnetic field (ELF EMF) radiation. In IOP Conference Series: Materials Science and Engineering (Vol. 298, No. 1, p. 012007). IOP Publishing.

[9] IEC International Electrotechnical Commission. (2005). Human Exposure to Radio Frequency Fields from Hand-Held and BodyMounted Wireless Communication Devices-Human Models, Instrumentation, and Procedures to Determine the Specific Absorption Rate (SAR) for Hand-Held Devices Used in Close Proximity to the Ear (Frequency Range of $300 \mathrm{MHz}$ to $3 \mathrm{GHz}$ ). International Standard, 62, 209.

[10] Peyman, A., \& Gabriel, C. (2007). Development and characterisation of tissue equivalent materials for frequency range 30-300MHz. Electronics Letters, 43(5), 19-20.

[11] Grandolfo, M. (2009). Worldwide standards on exposure to electromagnetic fields: an overview. The Environmentalist, 29(2), 109117.

[12] Cámara de Comercio de Lima, "Boletín mensual de importaciones en Perú". Boletín informativo Cámara de Comercio de Lima, vol. 48, pp. 10-14, 2017, [Online] Available at: https://camaralima.org.pe/ RepositorioAPS/0/0/par/BOLETINIMPO2017-12/DICIEMBRE\%20 IMPORTACION11.pdf (Accessed: 15 May 2019).

[13] Diario Gestión, “¿Cuáles son las marcas de telefonía móvil más consumidas por los peruanos?", August 2017, [Online] Available at: https:/camaralima.org.pe/RepositorioAPS/0/0/par/BOLETINIMPO2017
-12/DICIEMBRE\%20IMPORTACION11.pdf (Accessed: 13 May 2019).

[14] Melly F., "Estas serían las marcas de móviles más consumidas por los peruanos", PeruSmart, August 2017, [Online] Available at: http://www.perusmart.com/5-marcas-moviles-peruanos/ (Accessed: 14 May 2019).

[15] Diario El Comercio, "Smartphones: estos son los tres teléfonos más utilizados en el Perú", El Comercio, September 2017, [Online] Available at: https://elcomercio.pe/tecnologia/moviles/smartphones-son-trestelefonos-utilizados-peru-noticia-459367 (Accessed: 15 May 2019).

[16] DeviceAtlas, “The Mobile Web Intelligence Report Q2 2017”, August 2017

[17] Device Specifications comparisons, news and reviews, Samsung Galaxy J7 [Online] Available at: https://www.devicespecifications.com/es/ model/6b4f34a8

[18] Movil Zona, Samsung Galaxy J7 [Online] Available at: https://www.movilzona.es/samsung/galaxy-j7/

[19] Bundesamt für Strahlenschutz, SAR search for Samsung Galaxy J7, 2019 [Online] Available at: http://www.bfs.de/SiteGlobals/Forms /Suche/BfS/EN/SARsuche_Formular.html

[20] Microwave Vision Group (MVG), User Manual OpenSAR V5 Software, Brest, France, 2013.

[21] Butet R., Microwave Vision Group (MVG), Presentation ComoSAR, Instituto Nacional de Investigación y Capacitación de Telecomunicaciones (INICTEL-UNI), Lima, Peru, Dec. 2018. 